\title{
EVALUATING THE EFFECT OF URBAN RENEWAL PROVISIONS ON RESIDENTIAL SATISFACTION (CASE STUDY: RENEWAL PLAN OF KHOOBBAKHT NEIGHBORHOOD AT IMAM ALI DISTRICT IN TEHRAN)
}

\author{
Hassan Sajjadzadeh \\ Assistant Professor, Urban Design Faculty, Bu-Ali Sina University, Hamedan, Iran \\ h.sajadzadeh@gmail.com \\ Shahrzad Parto \\ Phd Candidate in Urban Design, Bu-Ali Sina University, Hamedan, Iran \\ parto.shahrzad@gmail.com \\ Kamyar Palizi \\ MA in Sustainable Architecture, Iran University of Science and Technology, Tehran, Iran \\ kamyar.palizi@gmail.com
}

\begin{abstract}
With regard to increasing importance of urban regeneration, assessment of previous provisions is considered as a major step due to effect of urban renewal on quality of life and the necessity to use dilapidated fabrics in line with goals of sustainable development and avoidance from urban sprawl. Since residents are the main beneficiaries of urban renewal and this should come to realize aiming at improving their satisfaction with living area, in the present research the measure of residential satisfaction has been used, mentioned as a suitable index to determine desirability of living area and effects of provisions made for it. To measure variables, five-point Likert questionnaire has been used as the research questionnaire; to analyze data and test research hypotheses, one-sample t-test has been used; to compare extent of satisfaction in three groups including centralized renewal, semi-centralized and decentralized renewal, one-way variance analysis has been used. Results from research indicate that neighborhood renewal has not had a significant effect on residential satisfaction in it, resulted in reduction of satisfaction extent in most of indices especially social indices. Neighborhood renewal has led to increase of satisfaction in some physical indices such as physical quality of residential unit. This indicates that attention has been merely focused on physical dimension instead of considering all the components of residential satisfaction. Another important result is higher extent of satisfaction among residents with the purpose of decentralized renewal, which this result indicates the necessity to change from authoritarian modernization models to micro scale, participative and community-oriented models and avoidance from prescribing prearranged physical plans and the necessity to use facilitators public institutions.
\end{abstract}

Keywords: residential satisfaction, urban renewal, centralized renewal, participative renewal, Khoobbakht neighborhood

\section{INTRODUCTION}

More than 130 thousand hectares of urban fabrics in the country, i.e. about 30 percent of the urban fabrics composed from dilapidated fabrics, aimed at urban renewal provisions. In these areas, among a population of over 17 million, about 20 percent of the urban population of the country is residents (government information website, 2014).

Since residents are major beneficiaries of neighborhoods aimed at proposing urban regeneration any intervention affects all their daily life dimensions, their preferences and demands should be specifically taken into account by decision makers (Zheng et al. 2014). Indeed, urban renewal and rehabilitation should come to realize with the purpose of improvement of residents' welfare, 
improvement of identity of neighborhood, increase of their belonging to place of their living area, improvement in quality of life and increase of their residential satisfaction at all dimensions. Therefore, to examine effects of urban renewal on reduction or increase of residents' satisfaction, the present research has been conducted aiming at examining existence or lack of this relationship.

In thisresearch research, an attempt has been made to examine and compare the relationship between residential satisfaction and recreation and renewal of residential environment in a number of renewal models experienced in residential neighborhoods. In this regards, the satisfaction level among the residents of khoobbakht at district Imam Ali(AS) in Tehran has been measured after detecting criteria of residential satisfaction based on world literature. Selection of khoobbakht at district Imam Ali (AS) in Tehran as the case study is of great importance since a wide range of renewal models have been tested in it.

In this regards, the present research has intended to give response to this question whether renewal models and actions in khoobbakht including centralized and up to down renewal model, semicentralized renewal model and decentralized renewal model have led to improvement in residents' satisfaction with their living environment or not. Under the relationship, whether effect of urban renewal on each of residential satisfaction dimensions has been more tangible in each of tested models.

\section{LITERATURE REVIEW}

The studies on satisfaction with residential environment have been conducted with various purposes including evaluation of existing conditions of residential environment and their comparison with residents' needs(Katitilla,1993; Salleh,2008), measurement of quality of life(Calderion,2011; Galster\&Hesser, 1981), evaluation of quality of project(Lara\& Bekker, 2012; Liu, 2013). Further some studies have examined the relationship between residential satisfaction with other concepts and indices. For instance, $\operatorname{Smith}(2011)$ in his $\mathrm{PhD}$ thesis has examined the relationship between three concepts of residential satisfaction, sense of place and sense of belonging to place(Smith, 2011). A variety of research have evaluated extent of residential satisfaction and its effect on decision to continue living or decision to displace living area(Fang, 2005).

In Iran, few studies have been conducted about concept of residential satisfaction. Rafieian et al have examined residents' satisfaction with residential complexes at Navvab neighborhood and have evaluated extent of residents' satisfaction at Navvab neighborhood from various perspectives (Rafieian et al. 2009). Rezaei \& Kamaei zadeh have examined extent of residents' satisfaction with Maskan Mehr complexes (Rezaei \& Kamaei zadeh, 2013). Ghiaei et al.(2013) have measured residential satisfaction in Farabi Medical Complex(Ghiaei et al. 2013).

Therefore, as observed in domestic literature, attention to residential satisfaction in studies has centralized to residential complexes and less attention has centralized to this concept and its measurement at scale of a neighborhood.

\section{CONCEPT OF RESIDENTIAL SATISFACTION}

In existing literature, concept of residential satisfaction has been defined in two general ways; some researchers have known residential satisfaction dependent on residents' understanding from the extent of access to their goals and ideals at their residential environment (Galster, 1987). In this approach, satisfaction refers to a process of evaluation and comparison of existing and expected conditions(Parker\& Mathews, 2001), under which residential satisfaction specifically refers to a function of distance between the person's needs and ideals and existing conditions of residential environment(Varady\& Preiser, 1998). This implies that people seek residence in an environment that assists them to achieve their expectations and enable them to achieve their goals. Therefore, the more residential environment has the facilitator role, the more people's residential satisfaction (Ibem\& Aduwo, 2013).

On the other hand, Galster(1987) has mentioned that in another approach people are well informed to consider the basic quantities and qualities as the ideal standards from various aspects of their 
residential area based on their experiences, needs and ideals, made an attempt to evaluate their residential environment based on comparison with these standards. If the existing conditions have less gap with their basic image, the satisfaction with residential environment will be experienced, otherwise dissatisfaction with residential environment will be experienced (Ibem\& Aduwo, 2013).

\section{MEASUREMENT MODELS OF RESIDENTIAL SATISFACTION}

Most of studies related to residents' satisfaction can be classified in two groups(Potter et al., 2001), i.e. the first group refers to the studies which consider the residents' satisfaction as a criterion of the evaluation of quality of residential environment, known the residents' satisfaction as a dependent variable(Marans\&Rodgers,1975), and the second group of studies knew satisfaction with residential environment as a precondition for behavior and as a result assumed it as an independent variable(Newman\&Duncan, 1979; Speare, 1974). Therefore, a comprehensive and integrative consideration of residential satisfaction must be determined by means of a theoretical framework, known the residents' satisfaction as a variable dependent on quality and features of residential environment and assumed it as a variable which causes a certain behaviors. Amerigo\& Aragones(1990) made an attempt to provide a theoretical model through examining how a person interacts with environment(image 1).

This model displays the elements which cause a resident's satisfaction and knows the residential satisfaction as a precondition for general satisfaction with life. In this regards, the studies on residents' satisfaction have addressed proposing a model and framework based on the factors related to their area, problem and goal.

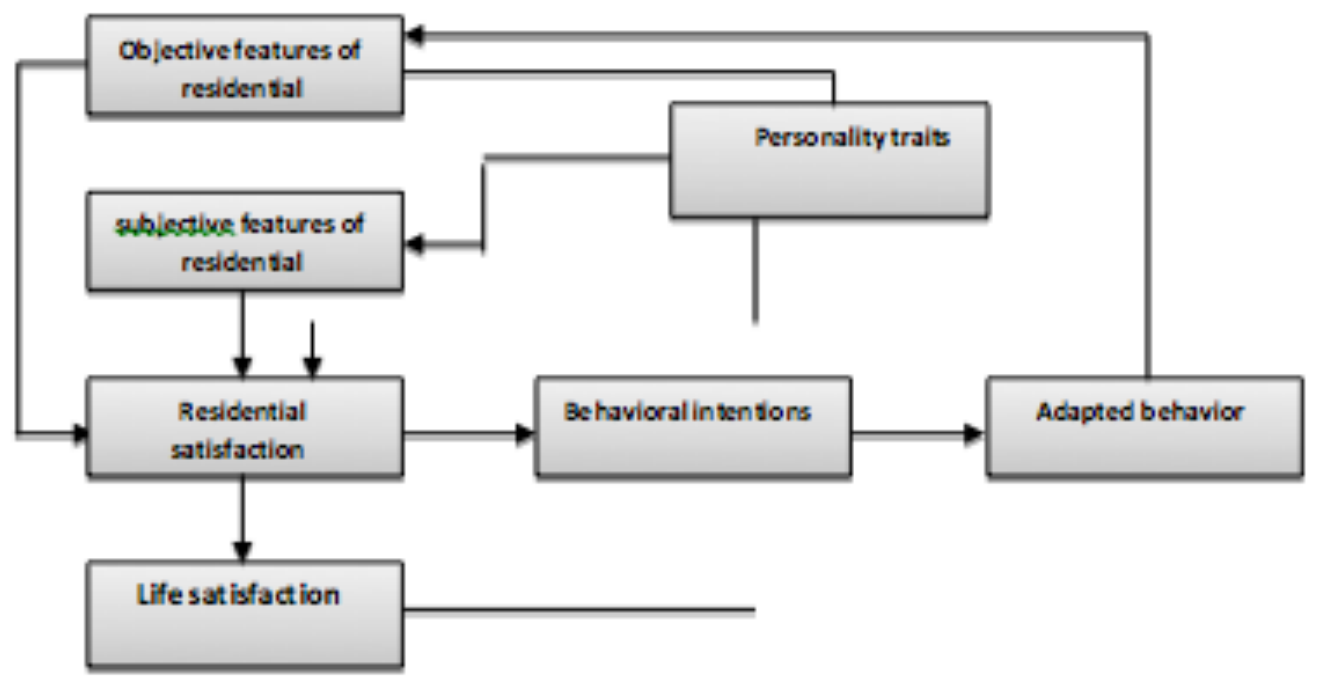

Image 1. Measurement model of residential satisfaction (Amerigo\& Aragones, 1997) 
DIMENSIONS OF RESIDENTIAL SATISFACTION

Results from the related works indicate effect of objective and subjective dimensions on residents' satisfaction(Table 1).

Table 1. Dimensions and indices of residential satisfaction

\begin{tabular}{|c|c|c|c|}
\hline \multirow{2}{*}{\multicolumn{2}{|c|}{$\begin{array}{l}\text { Dimension } \\
\text { Individual }\end{array}$}} & Index & \multirow{8}{*}{$\begin{array}{l}\text { Satsangi\&Kearns, 1992; Mohit et al., 2010; } \\
\text { Caldieron, 2011; Kahraman,2013; Brown et al., } \\
\text { 2005; Salleh et al., 2012; Mohit et al., 2010; Lu, } \\
\text { 1999; Perez et al., 2001 ;Amole, 2012; Salleh et al., } \\
\text { 2012; James et al., 2009; Chapman\&Lombard, } 2006\end{array}$} \\
\hline & & Age & \\
\hline \multirow{6}{*}{\multicolumn{2}{|c|}{ Individual }} & Previous and current & \\
\hline & & Education status & \\
\hline & & Job status & \\
\hline & & Financial afford to pay & \\
\hline & & type of housing tenure & \\
\hline & & Residence time & \\
\hline \multirow{10}{*}{ 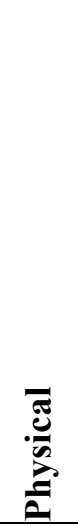 } & \multirow{4}{*}{$\begin{array}{l}\text { Surrounding } \\
\text { environment }\end{array}$} & road traffic & Varady, 1983 \\
\hline & & Urban landscape in the & Rohe\& Stegman, 1994 \\
\hline & & The number and quality & Smith, 2011: 29 \\
\hline & & Population and & James et al., 2009; Perez et al., 2001 \\
\hline & Residential & Number of rooms of & Zanuzdana et al., 2012; Ukoha\& Beamish, 1997 \\
\hline & & \multirow{2}{*}{$\begin{array}{lcr}\text { Quality } & \text { of } & \text { indoor } \\
\text { Access } & \text { to } & \text { training }\end{array}$} & Zanuzdana et al., 2012; Ukoha\& Beamish, 1997 \\
\hline & Access to & & Campbell et al., 1976; Turkoglu, 1997 \\
\hline & urban & Access to health care & Campbell et al., 1976; Turkoglu, 1997 \\
\hline & & Access to shopping & Turkoglu, 1997;Campbell et al., 1976; Salleh, 2008 \\
\hline & & $\begin{array}{l}\text { Access } \\
\text { transport }\end{array}$ to public & Turkoglu, 1997 \\
\hline \multirow{6}{*}{\multicolumn{2}{|c|}{ Social }} & \multirow{2}{*}{$\begin{array}{l}\text { friends and relatives in } \\
\text { Social interactions }\end{array}$} & Allen, 1991 \\
\hline & & & Parkes et al., 2002; Salleh, 2008; Mohit et al., 2010 \\
\hline & & Participation and & Zannuzdana et al., 2012 \\
\hline & & The sense of belonging & Amerigo\&Aragones, 1997; Young et al., 2004 \\
\hline & & Stability of & Kasarda\& Janowtz, 1974 \\
\hline & & perceived safety of & Adams, 1992; Carro et al., 2010 \\
\hline \multirow{2}{*}{\multicolumn{2}{|c|}{ Economic }} & $\begin{array}{l}\text { Value of residential unit } \\
\text { Job opportunities }\end{array}$ & Kaitille, 1993; Varady\& Carroza, 2000; Baiden et \\
\hline & & Job opportunities & Smith, 2011 \\
\hline \multirow{2}{*}{\multicolumn{2}{|c|}{ General satisfaction }} & \multirow{2}{*}{$\begin{array}{lr}\text { Satisfaction with living } \\
\text { Decision } & \text { upon }\end{array}$} & Amerigo\&Aragones, 1997; Young et al., 2004 \\
\hline & & & Fang, 2005; Ibem\& Aduwo, 2013 \\
\hline
\end{tabular}

\section{RESEARCH METHOD}

closed questionnaire has been used to measure the research variables. The research questionnaire develops from five major sections, i.e. the first section relates to individual indices or demographic variables, the second section relates to measurement of physical indices, the third section relates to social indices, the fourth section relates to economic indices, and the fifth section relates to measurement of residents' general satisfaction. Except for the first section of questionnaire in which a specific range has been used well suited to the related item, range of all other sections of questionnaire includes five-point Likret scale. To examine validity of questionnaire, the logical method has been used to determine validity based on content validity in which quantity and quality of questions are examined from point of view of experts. To measure reliability, Cronbach's $\alpha$ coefficient has been used. Cronbach's $\alpha$ coefficients of each of research variables have been summarized in table 1 . To analyze demographic variables of research and get familiar with the research sample, descriptive statistics were used. To test research hypotheses, one-sample t-test has been used. Further, to test 
difference on extent of residential satisfaction among three groups (centralized, semi-centralized and decentralized), ANOVA was used. Software SPSS was used for the considered tests.

Table 2. Evaluation of reliability of research questionnaire

\begin{tabular}{|l|l|l|}
\hline Variables or indices & Items & Cronbach's $\boldsymbol{\alpha}$ \\
\hline Physical indices & 9 & 0.70 \\
\hline Social indices & 6 & 0.71 \\
\hline Economic indices & 2 & 0.75 \\
\hline General satisfaction & 2 & 0.78 \\
\hline Sum & 19 & 0.82 \\
\hline
\end{tabular}

\section{RESEARCH SCOPE}

Khoobbakht neighborhood has been located at eastern south of Tehran along Imam Ali highway. Possession around Khoobbakht street had started since 2003 before providing the renewal plan of Khoobbakht neighborhood due to adaptation with the predicted route of Imam Ali(AS) highway. Yet the early route of highway has changed and adapted to the current route based on plan of highways in Tehran. Therefore, a large number of the Nos which had been destroyed remained without use, and this can be known as one of the major reasons for urban management decision making upon implementation of renewal plan of neighborhood. Followed by establishment of Imam Ali highway and the problems resulted from establishment of this highway at surrounding areas to create a suitable framework for renewal of old fabric with neighborhood-oriented outlook, comprehensive plan for renewal of Imam Ali which had specified the major passages network, use of zones, mean construction density and population density together with share of each of developing neighborhoods among the uses and population was prepared(Andalib et al. 2008, p. 50); with regard to the demolitions at Khoobbakht neighborhood, the urban landscape plan at Khoobbakht neighborhood which had neighborhood scale was prepared as the first sample and implemented with an approach known with participatory renewal(Andalib et al. 2008, p. 50).

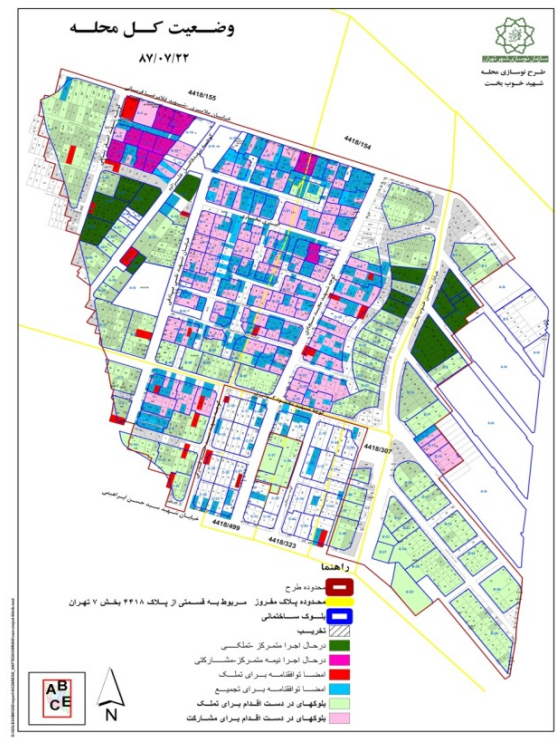

Image 2. The renewal plan of Khoobbakht neighborhood(urban landscape plan of Khoobbakht, 1387) 
In this regards, renewal plan of Imam Ali which was known with neighborhood-oriented participatory renewal has been implemented at three levels. at the first level ownership of land has been suggested to create service uses and open spaces and create uses with economic value added such as commercial complexes. At this stage, the method "new houses instead of old ones" was used. The mentioned provisions till this stage have been called with centralized renewal.

At the second level renewal organization of Tehran has taken action for acquisition of private investors to facilitate renewal at neighborhood and has granted huge legal and financial supports for investors and persuaded them for investment at old fabric of neighborhood.

At the third level mentioned with decentralized renewal, the custodian system undertakes conducting the capital process of the city to old fabrics, prediction of value added uses, improvement of quality of residence and so forth through policy makings and applying persuasive policies(Andalib et al. 2008, p. $64)$.

In this regards, the statistical population consists of three groups of residents. Cochran formulate has been displayed below to calculate the sample size:

$$
n=\frac{t^{2}(p . q)}{d^{2}}=\frac{1.96^{2}(0.5 * 0.5)}{0.11^{2}}=66
$$

\section{DISCUSSION}

\section{DESCRIPTIVE FINDINGS OF RESEARCH}

The classification of each of demographic variables has been summarized in table below based on 73 respondents.

Table 3. Classification and descriptive statistics of demographic variables

\begin{tabular}{|c|c|c|c|}
\hline Variables & Items & Frequency & $\%$ \\
\hline \multirow[t]{4}{*}{ Age } & Under 30 years old & 12 & $16 \%$ \\
\hline & $30-40$ years old & 23 & $32 \%$ \\
\hline & $40-50$ years old & 12 & $16 \%$ \\
\hline & Above 50 years old & 23 & $32 \%$ \\
\hline \multirow[t]{2}{*}{ Gender } & Female & 35 & $48 \%$ \\
\hline & Male & 33 & $45 \%$ \\
\hline \multirow{2}{*}{$\begin{array}{l}\text { Area of previous } \\
\text { housing }\end{array}$} & Khoobbakht neighborhood & 52 & $71 \%$ \\
\hline & Other neighborhoods & 17 & $23 \%$ \\
\hline \multirow[t]{3}{*}{ Area of current housing } & Khoobbakht & 37 & $51 \%$ \\
\hline & Besat complex & 17 & $23 \%$ \\
\hline & Imam reza complex & 19 & $26 \%$ \\
\hline \multirow[t]{5}{*}{ Education status } & illiterate & 10 & $14 \%$ \\
\hline & Graduate School & 26 & $36 \%$ \\
\hline & Secondary Graduate & 9 & $12 \%$ \\
\hline & High school graduate & 22 & $30 \%$ \\
\hline & Student or bachelor graduate & 5 & $7 \%$ \\
\hline \multirow[t]{6}{*}{ Job status } & Self-employed job & 16 & $22 \%$ \\
\hline & Worker or staff & 7 & $10 \%$ \\
\hline & Retired & 10 & $14 \%$ \\
\hline & Housewife & 35 & $48 \%$ \\
\hline & Student & 1 & $1 \%$ \\
\hline & Unemployed & 2 & $3 \%$ \\
\hline Financial afford to pay & Have & 15 & $21 \%$ \\
\hline
\end{tabular}




\begin{tabular}{|l|l|l|l|}
\hline housing costs & Not have & 52 & $71 \%$ \\
\hline \multirow{3}{*}{ Type of housing tenure } & ownership & 25 & $34 \%$ \\
\cline { 2 - 4 } & Ownership without certificate & 33 & $45 \%$ \\
\cline { 2 - 4 } & Leased & 13 & $18 \%$ \\
\hline \multirow{3}{*}{ Residence time } & $1-3$ years & 24 & $33 \%$ \\
\cline { 2 - 4 } & $4-10$ years & 26 & $36 \%$ \\
\cline { 2 - 4 } & Over 10 years & 19 & $26 \%$ \\
\hline \multirow{3}{*}{ Type of renewal plan } & Centralized & 36 & $49 \%$ \\
\cline { 2 - 4 } & Semi-centralized & 19 & $26 \%$ \\
\cline { 2 - 4 } & Decentralized & 18 & $25 \%$ \\
\hline
\end{tabular}

\section{RESEARCH HYPOTHESES TESTING}

To measure research hypotheses, one-sample t-test was used. In this regards, $\mathrm{H}_{0}$ refers to average level and $\mathrm{H}_{1}$ refers to lower or higher level than average level of each of variables.

H0: value of the considered variable has not a significant difference with average value.

H1: value of the considered variable has a significant difference with average value.

In this test, mean of values of each of variables is compared regarding five-point likret scale with the assumed value(3).

Table 4. Research hypotheses testing (one-sample t-test)

\begin{tabular}{|c|c|c|c|c|c|}
\hline \multicolumn{2}{|c|}{ Residential satisfaction indices } & \multirow{2}{*}{$\begin{array}{l}\text { Mean } \\
2.89 \\
\end{array}$} & \multirow{2}{*}{$\begin{array}{l}\begin{array}{l}\text { t- } \\
\text { statisti } \\
\text { cs }\end{array} \\
-0.683\end{array}$} & \multirow{2}{*}{$\begin{array}{l}\text { sig } \\
0.496\end{array}$} & \multirow{2}{*}{$\begin{array}{l}\text { Result } \\
\begin{array}{l}\text { Lack of difference with } \\
\text { mean }\end{array}\end{array}$} \\
\hline $\begin{array}{l}\text { Physical } \\
\text { indices }\end{array}$ & Reduction of road traffic & & & & \\
\hline & Improvement in urban landscape & 3.47 & 3.006 & 0.004 & $\begin{array}{l}\text { Positive difference with } \\
\text { mean }\end{array}$ \\
\hline & Green and public space & 2.64 & -2.476 & 0.016 & $\begin{array}{l}\text { Negative difference with } \\
\text { mean }\end{array}$ \\
\hline & Population density & 2.41 & -4.154 & 0.000 & $\begin{array}{l}\text { Negative difference with } \\
\text { mean }\end{array}$ \\
\hline & Access to health care services & 2.78 & -1.670 & 0.099 & $\begin{array}{l}\text { Lack of difference with } \\
\text { mean }\end{array}$ \\
\hline & Access to shopping centers & 2.95 & -0.379 & 0.706 & $\begin{array}{l}\text { Lack of difference with } \\
\text { mean }\end{array}$ \\
\hline & Access to leisure centers & 2.49 & 3.746 & 0.000 & $\begin{array}{l}\text { Negative difference with } \\
\text { mean }\end{array}$ \\
\hline & Access to public transport & 3.12 & -0.767 & 0.446 & $\begin{array}{l}\text { Lack of difference with } \\
\text { mean }\end{array}$ \\
\hline & Quality of residential unit & 3.36 & 2.076 & 0.041 & Positive difference with \\
\hline
\end{tabular}


The Turkish Online Journal of Design, Art and Communication - TOJDAC August 2016 Special Edition

\begin{tabular}{|c|c|c|c|c|c|}
\hline & & & & & mean \\
\hline \multirow[t]{6}{*}{$\begin{array}{l}\text { Social } \\
\text { indices }\end{array}$} & $\begin{array}{l}\text { Friends and relatives in } \\
\text { neighborhood }\end{array}$ & 2.56 & 4.174 & 0.000 & $\begin{array}{l}\text { Negative difference with } \\
\text { mean }\end{array}$ \\
\hline & Social interactions & 2.47 & -2.832 & 0.000 & $\begin{array}{l}\text { Negative difference with } \\
\text { mean }\end{array}$ \\
\hline & Stability of neighborhood & 2.30 & -5.482 & 0.000 & $\begin{array}{l}\text { Negative difference with } \\
\text { mean }\end{array}$ \\
\hline & Perceptional security of residents & 2.55 & -2.789 & 0.007 & $\begin{array}{l}\text { Negative difference with } \\
\text { mean }\end{array}$ \\
\hline & $\begin{array}{l}\text { Sense of belonging } \\
\text { neighborhood }\end{array}$ & 2.81 & -1.262 & 0.211 & $\begin{array}{l}\text { Lack of difference with } \\
\text { mean }\end{array}$ \\
\hline & Participation in local institution & 2.70 & 1.812 & 0.074 & $\begin{array}{l}\text { Lack of difference with } \\
\text { mean }\end{array}$ \\
\hline \multirow[t]{2}{*}{$\begin{array}{l}\text { Economic } \\
\text { indices }\end{array}$} & Value of residential unit & 2.96 & 0.215 & 0.831 & $\begin{array}{l}\text { Lack of difference with } \\
\text { mean }\end{array}$ \\
\hline & Job opportunities & 2.68 & -2.385 & 0.020 & $\begin{array}{l}\text { Lack of difference with } \\
\text { mean }\end{array}$ \\
\hline \multirow{2}{*}{$\begin{array}{l}\text { General } \\
\text { satisfactio } \\
\text { n }\end{array}$} & $\begin{array}{l}\text { Satisfaction with living } \\
\text { environment }\end{array}$ & 3.23 & 1.602 & 0.113 & $\begin{array}{l}\text { Lack of difference with } \\
\text { mean }\end{array}$ \\
\hline & $\begin{array}{l}\text { Decision upon continuing } \\
\text { residence }\end{array}$ & 2.68 & 2.053 & 0.044 & $\begin{array}{l}\text { Negative difference with } \\
\text { mean }\end{array}$ \\
\hline
\end{tabular}

With regard to absolute t-value for indices of reduction in road traffic, access to health care and training services, access to shopping centers, access to public transport, sense of belonging to neighborhood, participation in local institutions, value of residential units, job opportunities and satisfaction with living environment which is under 1.96, it can conclude that after implementing three-dimensional plans of residential renewal, residents' satisfaction with indices of reduction in road traffic, access to health care and training services, access to shopping centers, access to public transport, sense of belonging to neighborhood, participation in local institutions, value of residential units, job opportunities and satisfaction with living environment have not had a significant change, evaluated at average level.

With regard to t-statistics for indices of green space and public space, population density, access to leisure centers, relationship with friends and relatives in neighborhood, social interactions, stability of neighborhood, residents' perceptional security and decision upon continuing living which are greater than 1.96, it can conclude after implementing three-dimensional plans of residential renewal, residents' satisfaction with indices of public and green space, population density, access to leisure centers, relationship with friends and relatives in neighborhood, social interactions, stability of neighborhood, residents' perceptional security and decision upon continuing living have been measured at low level.

With regard to t-statistics for the indices of improvement in urban landscape and quality of residential unit which are greater than 1.96, it can conclude that after implementing three-dimensional plans of residential renewal, residents' satisfaction with indices of improvement in urban landscape and quality 
of residential unit has been evaluated at level greater than average. Values of mean related to each of indices have been proposed in table below indicating these results.

\section{TESTING DIFFERENCE OF RESIDENTIAL SATISFACTION OF THREE GROUPS OF RENEWAL PLANS (CENTRALIZED, SEMI-CENTRALIZED AND DECENTRALIZED)}

To test difference in residential satisfaction level of the residents who attended in each of three renewal models, one-way analysis of variance (ANOVA) has been used (table 5). As observed in table below, sig is greater than 0.05 for the indices of reduction of road traffic, improvement in urban landscape, access to training and health care services, access to shopping centers, access to public transport, quality of residential unit, relationship with friends and relatives in neighborhood, social interactions, stability of neighborhood, residents' perceptional security, sense of belonging to neighborhood, participation in local institutions, job opportunities, satisfaction with living environment and decision upon continuing living. Therefore, there is not a significant difference between residents of three renewal plans for these indices. Sig is less than 0.05 for indices of green and public space, population density, access to leisure centers and value of residential unit. Therefore, there is a significant difference between residents of three renewal plans for these indices, that residents of these three renewal plans evaluated level of these indices at their living area so different.

Table 5. Results of ANOVA to test difference in residential satisfaction of three groups of renewal plans

\begin{tabular}{|c|c|c|c|c|c|}
\hline \multicolumn{2}{|c|}{ Indices of residential satisfaction } & \multirow{2}{*}{$\begin{array}{l}\text { Sig } \\
155 / 0\end{array}$} & \multirow{2}{*}{$\begin{array}{l}\text { Error } \\
\text { value }\end{array}$} & \multirow{2}{*}{$\begin{array}{l}\text { F } \\
914 / 1\end{array}$} & \multirow{2}{*}{$\begin{array}{l}\text { Result } \\
\begin{array}{l}\text { Lack of difference of } \\
\text { means }\end{array}\end{array}$} \\
\hline $\begin{array}{l}\text { Physical } \\
\text { indices }\end{array}$ & Reduction in road traffic & & & & \\
\hline & Improvement in urban landscape & $192 / 0$ &.$/ .0$ & $688 / 1$ & $\begin{array}{l}\text { Lack of difference of } \\
\text { means }\end{array}$ \\
\hline & Public and green space & $000 / 0$ & $\cdot / \cdot 0$ & $596 / 8$ & difference of means \\
\hline & Population density & $40 / 0$ & $\cdot / \cdot \Delta$ & $360 / 3$ & difference of means \\
\hline & Access to health care services & $656 / 0$ & $\cdot / \cdot 0$ & $424 / 0$ & $\begin{array}{l}\text { Lack of difference of } \\
\text { means }\end{array}$ \\
\hline & Access to shopping center & $546 / 0$ & $\cdot / \cdot \Delta$ & $610 / 0$ & $\begin{array}{l}\text { Lack of difference of } \\
\text { means }\end{array}$ \\
\hline & Access to leisure center & $018 / 0$ &.$/ .0$ & $234 / 4$ & difference of means \\
\hline & Access to public transport & $754 / 0$ & $\cdot / \cdot \Delta$ & $296 / 6$ & $\begin{array}{l}\text { Lack of difference of } \\
\text { means }\end{array}$ \\
\hline & Quality of residential unit & $810 / 0$ & $\cdot / \cdot \Delta$ & $212 / 0$ & $\begin{array}{l}\text { Lack of difference of } \\
\text { means }\end{array}$ \\
\hline \multirow[t]{3}{*}{$\begin{array}{l}\text { Social } \\
\text { indices }\end{array}$} & $\begin{array}{l}\text { Relatives and friends in } \\
\text { neighborhood }\end{array}$ & $684 / 0$ & $\cdot / \cdot \Delta$ & $381 / 0$ & $\begin{array}{l}\text { Lack of difference of } \\
\text { means }\end{array}$ \\
\hline & Social interactions & $447 / 0$ &.$/ \cdot 0$ & $816 / 0$ & $\begin{array}{l}\text { Lack of difference of } \\
\text { means }\end{array}$ \\
\hline & Stability of neighborhood & $261 / 0$ &.$/ . \Delta$ & $368 / 1$ & Lack of difference of \\
\hline
\end{tabular}


The Turkish Online Journal of Design, Art and Communication - TOJDAC August 2016 Special Edition

\begin{tabular}{|c|c|c|c|c|c|}
\hline & & & & & means \\
\hline & Perceptional security of residents & $145 / 0$ &.$/ .0$ & $982 / 1$ & $\begin{array}{l}\text { Lack of difference of } \\
\text { means }\end{array}$ \\
\hline & $\begin{array}{l}\text { Sense of belonging to } \\
\text { neighborhood }\end{array}$ & $252 / 0$ &.$/ .0$ & $407 / 1$ & $\begin{array}{l}\text { Lack of difference of } \\
\text { means }\end{array}$ \\
\hline & Participation in local institution & $684 / 0$ &.$/ .0$ & $382 / 1$ & $\begin{array}{l}\text { Lack of difference of } \\
\text { means }\end{array}$ \\
\hline Economi & Value of residential unit & $007 / 0$ & .1 .0 & $318 / 5$ & difference of means \\
\hline & Job opportunities & $651 / 0$ &.$/ .0$ & $433 / 0$ & $\begin{array}{l}\text { Lack of difference of } \\
\text { means }\end{array}$ \\
\hline $\begin{array}{l}\text { General } \\
\text { satisfacti }\end{array}$ & $\begin{array}{l}\text { Satisfaction with living } \\
\text { environment }\end{array}$ & $500 / 0$ & .1 .0 & $700 / 0$ & $\begin{array}{l}\text { Lack of difference of } \\
\text { means }\end{array}$ \\
\hline & Decision upon continuing living & $824 / 0$ &.$/ .0$ & $194 / 0$ & $\begin{array}{l}\text { Lack of difference of } \\
\text { means }\end{array}$ \\
\hline
\end{tabular}

Mean and priority of residents' residential satisfaction in each of renewal plans with indices of green and public space, population density, access to leisure centers and value of residential unit have been summarized in table below, through which it can determine priority of each of renewal plans(centralized, semi-centralized and decentralized) to each other. For all the indices of public and green space, population density, access to leisure centers, value of residential unit, residents' satisfaction level in decentralized renewal plan is greater than semi-centralized renewal plan. In other words, the more moving from centralized renewal plans to decentralized plans, residents' residential satisfaction with indices of green and public spaces, population density, access to leisure centers and value of residential unit increase. In other words, residents of decentralized renewal plans have more satisfaction in indices of green and public space, population density, access to leisure centers and value of residential unit than residents of semi-centralized and centralized renewal plans.

Table 6. Order of residential satisfaction in three renewal plans

\begin{tabular}{|c|c|c|c|c|c|c|}
\hline Satisfact & 1 indices & \multirow{2}{*}{$\begin{array}{l}\text { Renewal plan } \\
\text { Centralized }\end{array}$} & \multirow{2}{*}{$\begin{array}{l}\begin{array}{l}\text { No of } \\
\text { responde } \\
\text { nts }\end{array} \\
36 \\
\end{array}$} & \multirow{2}{*}{$\begin{array}{l}\text { Mean } \\
22 / 2\end{array}$} & \multirow{2}{*}{$\begin{array}{l}\text { Rank } \\
3\end{array}$} & \multirow{2}{*}{$\begin{array}{l}\text { Result } \\
\text { Satisfaction at low level }\end{array}$} \\
\hline \multirow{9}{*}{$\begin{array}{l}\text { Physical } \\
\text { indices }\end{array}$} & \multirow{3}{*}{$\begin{array}{l}\text { Green } \\
\text { and } \\
\text { public } \\
\text { space }\end{array}$} & & & & & \\
\hline & & semi- & 19 & $58 / 2$ & 1 & Satisfaction at relatively low \\
\hline & & decentralized & 18 & $55 / 3$ & 2 & Satisfaction at relatively low \\
\hline & \multirow{3}{*}{$\begin{array}{l}\text { Populati } \\
\text { on } \\
\text { density }\end{array}$} & centralized & 36 & $06 / 2$ & 3 & Satisfaction at low level \\
\hline & & semi- & 19 & $67 / 2$ & 2 & Satisfaction at relatively low \\
\hline & & decentralized & 18 & $82 / 2$ & 1 & Satisfaction at average level \\
\hline & \multirow{3}{*}{$\begin{array}{l}\text { Access } \\
\text { to } \\
\text { leisure } \\
\text { centers }\end{array}$} & centralized & 36 & $11 / 2$ & 3 & Satisfaction at low level \\
\hline & & semi- & 19 & $84 / 2$ & 2 & Satisfaction at average level \\
\hline & & decentralized & 18 & $89 / 2$ & 1 & Satisfaction at average level \\
\hline
\end{tabular}




\begin{tabular}{|c|c|c|c|c|c|c|}
\hline \multirow{3}{*}{$\begin{array}{l}\text { Economic } \\
\text { indices }\end{array}$} & \multirow{3}{*}{$\begin{array}{l}\text { Value of } \\
\text { residenti } \\
\text { al unit }\end{array}$} & centralized & 36 & $36 / 2$ & 3 & Satisfaction at low level \\
\hline & & semi- & 19 & $50 / 3$ & 2 & $\begin{array}{l}\text { Satisfaction at relatively } \\
\text { hich lawal }\end{array}$ \\
\hline & & decentralized & 18 & $58 / 3$ & 1 & Satisfaction at relatively \\
\hline
\end{tabular}

\section{CONCLUSION}

The results indicate that renewal of Khoobbakht neighborhood has not had a significant effect on residents' satisfaction level, but extent of this effect is not the same in various dimensions and indices. No change has taken place in some of dimensions of residents' satisfaction before acting for renewal at the neighborhood, whereby this has not led to residents' satisfaction with renewal. For instance residents' satisfaction with indices of reduction of road traffic, access to training and health care services, access to shopping centers, access to public transport, sense of belonging to neighborhood, participation in local institutions, value of residential units, job opportunities and general satisfaction with living environment.

Concerning some of indices, an action to renewal of neighborhood has not just followed by a positive effect but also has led to reduction of residents' satisfaction at these areas. These factors including quantity and quality of public and green spaces, population density, access to leisure centers, relationship with friends and relatives in neighborhood, social interaction, stability of neighborhood, residents' perceptional security and decision upon continuing living have been evaluated less than average level.

Yet an action to renewal of Khoobbakht neighborhood has caused improvement in residents' satisfaction level just in some of the areas such as indices of urban landscape and quality of residential unit. This indicates that economic and social factors and quality of urban facilities and services have not been taken into account in renewal made based on urban landscape plan, so that this has had a negative impact on mentioned aspects.

The interesting points in the results above indicate that although renewal of Khoobbakht neighborhood has not had any effect on extent of residents' satisfaction, their motivation has reduced to continue living at the area, which this is contrary to most of the studies which had referred to direct relationship between residential satisfaction and decision upon continuing residence at residential environment.

Comparison of three centralized, semi-centralize and decentralized models associated to most of indices including indices of reduction of road traffic, improvement of the urban landscape, access to educational and health services, access to shopping centers, access to public transportation, quality of residential units (the physical indicators), relationship with friends and relatives in the neighborhood, social interactions, neighborhood stability, residents' perception of security, a sense of belonging to the neighborhood, participation in local institutions( social indices), job opportunities(economic indicators), satisfaction with living environment and decision upon continue living (indicator of overall satisfaction) indicated no significant difference among residents of three renewal projects; residents of each of renewal projects evaluated level of these indices at their living area the same. Concerning indices of public and green space, population density, access to leisure centers, value of residential unit, there is a significant difference between residents of three renewal models; residents of these three renewal projects evaluated level of these indices at their living area different. Concerning four indices of green and public space, population density, access to leisure centers, value of residential unit, extent of residents' satisfaction in decentralized renewal project is greater than semi-centralized renewal project.

In other words, the more moving from centralized renewal projects to decentralized renewal projects, residents' satisfaction with indices of green and public space, population density, access to leisure centers and value of residential unit increase. In other words, residents of decentralized renewal projects are more satisfied with indices of green and public space, population density, access to leisure centers and value of residential unit than residents of centralized and semi-centralized renewal 
projects. This indicates superiority of decentralized and participatory models and micro-scale provisions to centralized models and predetermined projects regardless of residents' needs and conditions and major beneficiaries of neighborhood.

\section{SUGGESTIONS}

With regard to the findings and results from this research, compliance with factors below seems effective to increase residential satisfaction under provisions to urban renewal;

-considering increasing residential satisfaction as the major goal in provisions of urban renewal

-changing approach from centralized and comprehensive renewal models to participatory and microscale models

-avoiding prescription of pre-determined physical projects without environmental and socioeconomic studies and evaluations

-avoiding residents' extensive displacements due to renewal provisions

-moving towards stable recreation of neighborhoods with a gradual process instead of extensive renewal

-considering all the dimensions and of residential satisfaction instead of attention to physical dimension

\section{REFERENCES}

Adams, R. E, (1992), Is happiness a home in the suburbs? The influence of urban versus suburban neighborhoods on psychological health, Journal of Community Psychology (20) 353-72.

Amerigo,M., Aragones, J. I. ( 1997), A theoretical and methodological approach to study of residential satisfaction, Journal of Environmental Psychology 17(1) 47-57.

Amerigo,M., Aragones, J. I. (1990), Residential satisfaction in council housing, Journal of Environmental Psychology (10) 313-325.

Andalib, AR., Haji Aliakbari, K. (2008), Renovation of Deteriorated Urban Areas, number 7: Dilapidated contxt's renovation with Khoobbakht neighborhood's residents' participation, Urban Renewal Organization of Tehran Publications.

Atkinson, R. (2004), The evidence on the impact of gentrification: new lessons for the urban renaissance?, European Journal of Housing Policy (4) 107-131.

Baiden P., Arkug., Luginaah, Asiedu, A. B. (2011), An assessment of residents' housing satisfaction and coping in Accra: Ghana, Journal of Public Health (19) 29-37.

Boyle, M. A., Kiel, K. A. ( 2001). A Survey of House Price Hedonic Studies of the Impact of Environmental Externalities, Journal of Real Estate Literature 9(2) 117-144.

Burby, R.J., Rohe, W.M. (1990). Providing for the housing needs of the elderly", Journal of the American Planning Association (56) 324-40.

Campell, A., Converse, P.E., Rodgers, W.J. (1976), The quality of American life: perceptions, evaluations, and satisfaction, Russell Sage Foundation, New York.

Caldieron, J. (2011), Residential satisfaction in La Perla informal neighborhood, San Juan: Puerto Rico, OIDA International Journal of Sustainable Development 2(11) 77-84.

Dahmaan, D.C. (1985), Assessments of neighborhood quality in metropolitan America, Urban Affairs Quarterly (20) 511-35.

Elsinga, M., \& Hockstra, J. (2005), Homeownership and housing satisfaction, Journal of Housing and the Built Environment (20) 301-324.

Fang, Y. (2005), Residential Satisfaction, Moving Intention and Moving Behaviours: A Study of Redeveloped Neighbourhoods in Inner-City Beijing, Journal of Housing Studies (21) 671-694.

Francescato, G., Weidemann, S.\& Anderson, J.(1989), Evaluating the built environment from the users point of view: an attitudinal model for residential satisfaction, NewYork, Plenum Press.

Galster, G. C., \& Hesser, G. W. (1981), Residential satisfaction: compositional and contextual correlates, Environmental and Behaviour, 13(6), 735-758. 
Ghiaee, MH., Azimi, Sh.\& Shahabian, P. (2013), measuring variables related to residential satisfaction with housing and neighborhood (Case study: Farabi residential complex), Journal of city identity (15) $49-60$.

Haji Aliakbari, K. (2011), Renovation of Deteriorated Urban Areas, number 10: facilitating and the establishing renovation facilitator offices in Tehran's dilapidated areas, Urban Renewal Organization of Tehran Publications.

Hashim, A. H. (2003), Residential satisfaction and social integration in public low cost housing in Malaysia Pertanika, Journal of Social Science and Humanities 11(1) 1-10.

Kahraman, Z. E. (2011). Urban Integration as A Multi-Dimensional Process, in Frank Eckardt ve John Eade (eds.), The Ethnically Diverse.

Kaitilla, S. (1993), Satisfaction with public housing in Papua New Guinea : The case of West Taraka housing scheme, Environment and Behavior (25) 514-45.

Kamp, I. V., Leidelmeijer, K., Marsman, G., Hollander, A. D. (2003), Urban environmental quality and human well-being towards a conceptual framework and demarcation of concepts; a literature study, Landscape and Urban Planning (65) 5-18.

Kasarda, J.D., Janowitz, M. (1974), Community attachment in mass society, American Sociological Review (39) 328-329.

Lu, M. (1999), Determinants of residential satisfaction: Ordered logit vs. Regression Models, Growth and Change (30) 264-87.

Marans, R.W., Rodgers, W. (1975), Toward an understanding of community satisfaction, in A.H. Hawley and V.P. Rock (eds.), Metropolitan America in Contemporary Perspective, Halstead, New York

Mohit, M. A., Ibrahim, M. I., Rashid, Y. R. (2010), Assessment of residential satisfaction in newly designed public low-cost housing in Kuala Lumpur: Malaysia, Habitat International (34) 18-27.

Onibokun, A. (1974), Evaluating consumers' satisfaction with housing, Journal of the American Institute of Planners (40) 189-200.

Parkes, A., Kearns, A., Atkinson, R. (2002), The determinants of neighborhood dissatisfaction, ESRC Centre for Neighborhood Research, Bristol.

Rafieian, M., Asgari, A., Asgarizadeh, Z. (2009), measuring the residential satisfaction of Navvab neighborhood, Journal of Human Geography Research (67) 53- 68.

Rezaei, M., Komaei Zadeh, Y. (2013), Evaluating the satisfaction of residents of Fatemieh housing complexes in Yazd, Journal of Urban Studies (5) 13- 26

Rohe, W.M., Stegman, M.A. (1994), The impact of home ownership on the social and political involvement of low-income people, Urban Affairs Quarterly 30(September) 152-72.

Salleh, A. N. A., Yosuf, B. N. A., Salleh, C. A. G., \& Johari, D. N. (2012), Tenant satis- faction in public housing and its relationship with rent arrears: Majlis Ban-Perak, Malaysia, International Journal of Trade, Economics and Finance 2(1) 10-18.

Salleh, A. G. (2008), Neighbourhood factors in private low-cost housing in Malaysia, Habitat International (32) 485-93.

Satsangi, M., Kearns, A. (1992). The use and interpretation of tenant satisfaction surveys in British social housing, environment and planning,Government and Policy (10) 318-331.

Smith, K.M. (2011), The Relationship between Residential Satisfaction, Sense of Community, Sense of Belonging and Sense of Place in a Western Australian Urban Planned Community, phd thesis in Edith Cowan University.

Speare, A. (1974), Residential satisfaction as an intervening variable in residential mobility, Demography,11, pp. 173-188.

Turkoglu, H. (1997), Residents' satisfaction of housing environments: the case of İstanbul, Turkey, Landscape and Urban Planning (39) 55-67.

Ukoha, O. M., Beamish J. O. (1997), Assessment of residents' satisfaction with public housing in Abuja:Nigeria, Habitat International (21) 45-460.

Varady, D. P. \& Preiser, W. F. E. (1998), Scattered-site public housing and housing satisfactionimplications for the new public housing program, Journal of the American Planning Association, 64, 189-207.

Varady, D. P., \& Carrozza, M. A. (2000), Towards a better way to measure customer satisfaction levels in public housing: a report from Cincinnati, Housing Studies 15(60) 797-825. 
Varaday, D.P. (1983), Determinants of residential mobility, Journal of the American Planning Association (49) 184-99.

Westaway, M.S. (2006), A longitudinal investigation of satisfaction with personal and environmental quality of life in an informal South African housing settlement, Doornkop: Soweto, Habitat International (30) 175-89.

Wiesenfeld, E. (1992), Public housing evaluation in Venezuela: A case study, Journal of Environmental Psychology (12) 213-23.

Zabihi, H., Habib, F., Rahbari Manesh, K. (2011), examining the relationship between the satisfaction of residential complexes and residential complex on human relations( case study: some residential complex in Tehran), Journal of city identity (8) 103- 119.

Zanuzdan ,A.,Khan,M.,Kraemer, A. (2012), Housing satisfaction related to health and importance of services in urban slums:evidence from Dhaka: Bangladesh, Social Indicators Reasearch (DOI 10.1007/s1 1205-012-0045-5).

http://www.dolat.ir/NSite/FullStory/Article 